\title{
ANALISIS PENGOLAHAN LIMBAH MEDIS PADAT PADA 2 (DUA) PUSKESMAS RAWAT INAP DAN 2 (DUA) PUSKESMAS NON RAWAT INAP DI KABUPATEN BANYUMAS TAHUN 2016
}

\author{
Ilham Khumaidi $^{1)}$, Agus Subagiyo ${ }^{2)}$, Teguh Widiyanto ${ }^{3)}$ \\ Jurusan Kesehatan Lingkungan, Politeknik Kesehatan Kemenkes Semarang, \\ Jl.Raya Baturaden KM 12 Purwokerto, Indonesia
}

\begin{abstract}
Abstrak
Pusat kesehatan masyarakat (puskesmas) merupakan salah satu unit pelayanan kesehatan yang dalam kegiatannya menghasilkan limbah medis maupun limbah non medis baik dalam bentuk padat maupun cair. Tujuan dari penelitian ini adalah untuk menganalisis sistem pengolahan limbah medis padat ada 2 (dua) Puskesmas Rawat Inap dan 2 (dua) Puskesmas Non rawat Inap di Kabupaten Banyumas.Metode penelitian yang digunakan adalah metode penelitian yang digunakan adalah metode penelitian deskriptif. Penelitian ini menggunakān pendekatan kualitatif. Proses pengolahan sampah yang di lakukan setiap puskesmas yang di teliti sama yaitu dari mulai penimbulan, pewadahan, pengumpulan, pengangkutan pengolahan dan pembuangan akhir sudah sama semua di setiap puskesmas sudah ada tempat sampah yang terpisah antar sampah medis dan non medis. Akan tetapi untuk plastik bewarna pewadahan belum dilaksanakan untuk Puskemas II Cilongok dan Puskesmas II Kembaran.Kesimpulan dari penitian ini adalah pengelolaan limbah medis padat pada Puskesmas I Sokaraja, Puskesmas I Cilongok, Puskesmas II Cilongok, dan Puskesmas II Kembaran dapat dikatakan sudah sesuai dengan pengelolaan limbah medis menurut Kepmenkes No 1428/MENKES/SK/XII/2006.Saran yang diberikan kepada Puskesmas di Kabupaten Banyumas memperbaiki pengelolaan limbah medis padat dan non medis khususnya untuk pelabelan tempat sampah, penggunaan kantong plastik bewarna, dan tempat penampungan yang harus ada.
\end{abstract}

Kata kunci : Limbah Medis Padat, Tempat Penampungan, Puskesmas

\begin{abstract}
Pusat Kesehatan Masyarakat (Puskesmas) is one of the health service units which form the activities produce medical waste or non-medical wastes both in solid and liquid waste. The purpose of this research is to analysis solid waste processing system in 2 (two) hospitalizing Puskesmas and 2 (two) non-hospitalizing Puskesmas in Banyumas regen.The method used in this research was descriptive research method. This research used qualitative approach.Processing that was done in each Puskesmas which was examined was the same those were arousal, provision of a container, collecting, transportation, processing, and final discharging were the same in every Puskesmas dust bins were also provided separately between medical bin and non-medical bin. But, for colored plastic trash the provision was not done in Puskesmas II Cilongok and Puskesmas II Kembaran. The conclusion of this research is that medical solid waste processing in Puskesmas I Sokaraja, Puskesmas I Cilongok, Puskesmas II Cilongok and PUskesmas II Kembaran were appropriate with medical waste processing according to Kepmenkes No 1428/MENKES/SK/XII/2006. The researcher suggests to Puskesmas in Banyumas regency to improve medical and non-medical solid waste processing especially for labeling the dust bins, the use of colored plastic, and provision place must be provided.
\end{abstract}

Keywords : Medical Solid Waste, Shelter, Puskesmas

\section{PENDAHULUAN}

Pusat kesehatan masyarakat (puskesmas) merupakan salah satu unit pelayanan kesehatan yang dalam kegiatannya menghasilkan limbah medis maupun limbah non medis baik dalam bentuk padat maupun cair.Limbah medis dalam bentuk padat di puskesmas biasanya dihasilkan dari kegiatan yang berasal dari ruang perawatan (bagi puskesmas rawat inap), poliklinik umum, poliklinik gigi, poliklinik ibu dan anak/KIA, laboratorium dan apotik. Sementara limbah cair biasanya berasal dari laboratorium puskesmas yang kemungkinan mengandung

1) Email : ilham12khumaidi@gmail.com

2) Email : agusgiyo@yahoo.co.id

3) Email : teguhwidiyanto007@gmail.com mikroorganisme, bahan kimia beracun, dan radioaktif (Suryati, 2009 : 42).

Menganalisis sistem Pengolahan Limbah Medis Padat Pada 2 (dua) Puskesmas Rawat Inap dan 2 (dua) Puskesmas Non rawat Inap Di Kabupaten Banyumas Tahun 2016

\section{BAHAN DAN METODE}

Metode penelitian yang digunakan adalah metode penelitian deskriptif. Penelitian ini menggunakan pendekatan kualitatif.Penelitian ini difokuskan pada proses pengolahan limbah medis padat di Puskesmas 
I Sokaraja, I Cilongok, II Cilongok, dan II Kembaran di Kabupaten Banyumas. Yang meliputi penimbulan pemilahan, pengumpulan, pemindahan dan pengangkutan, penyimpanan sementara, dan penanganan akhir.Data ini diperoleh dari hasil observasi (pengamatan), dokumentasi dan wawancara mendalam yang dilakukan terhadap informan baik informan utama/kunci maupun informan pendukung, mengenai berbagai hal yang berkaitan dengan upaya pengolahan limbah medis di Puskesmas I Sokaraja, I Cilongok, II Cilongok, dan II Kembaran di Kabupaten Banyumas.Pengambilan subyek penelitian dilakukan dengan metode snowball yaitu metode pengambilan subyek secara berantai untuk mengetahui informan yang potensial dan memahami mengenai pengolahan limbah medis Puskesmas I Sokaraja, I Cilongok, II Cilongok, dan II Kembaran di Kabupaten Banyumas.Teknik snowball ini dimulai dengan melakukan wawancara mendalam kepada informan kunci kemudian baru kepada informan pendukung. Informan kunci dalam penelitian ini diantaranya yaitu kepala puskesmas, kordinator bidang Pemberantasan Penyakit dan Penyehatan Lingkungan (P2PL), staff P2PL, dan cleaning service Puskesmas I Sokaraja, I Cilongok, II Cilongok, dan II Kembaran.

\section{III.HASIL DAN PEMBAHASAN}

\section{Hasil}

Berdasarkan keterangan beberapa informan terkait sejauh mana pengetahuan petugas medis dan petugas non medis tentang limbah medis padat, para informan dari Puskesmas I Sokaraja, Puskesmas I Cilongok, Puskesmas II Cilongok, dan Puskesmas II Kembaran memberikan pendapat yang relatif sama bahwa limbah medis adalah limbah sisa hasil pelayanan medis yang sudah tidak terpakai, jarum suntik, verban, botol infus, kain kasa, kapas, botol suntik dan lain-lain.

Dari 4 (empat) Puskesmas yang di teliti di Kabupaten Banyumas petugas sudah tau mana saja unit yang menimbulkan limbah medis padat. Yang paling banyak menimbulkan untuk puskesmas yang terdapat rawat inap pada IGD dan rawat inap, untuk puskesmas non rawat inap paling banyak di timbulkan pada unit pemeriksaan umum dan laboratorium.

Dari 4 (empat) Puskesmas yang di teliti di Kabupaten Banyumas sudah menyediakan tempat sampah di setiap unit pelayanannya. Tempat sampah medis yang berisi sampah medis basah seperti kain kasa kapas, botol infus dll, sedangkan ada juga tempat sampah safty box yang khusus sampah benda tajam seperti jarum suntik, botol suntik dll dan tempat sampah non medis.Sejak awal pembuangan, limbah yang dihasilkan dari kegiatan pelayanan kesehatan sudah dibuang secara terpisah, limbah medis dibuang di tempat limbah medis dan limbah non medis dibuang di tempat limbah non medis.
Kadang juga masih ada tercampur sampah medis dan non medis sehingga petugas cleaning service harus memilahnya lagi.

Proses pengumpulan dari ke empat puskesmas di lakukan pada sore hari dan setiap hari di kumpulkan oleh petugas cleaning service untuk di kumpulkan di TPS sementara.Proses pengakutan dilakukan setiap hari oleh petugas Cleaning servis. Akan tetapi untuk pengangkutan yang ada di Puskesmas II Cilongok dan Puskesmas II Kembaran masih pengangkutan secara manual belum ada troli untuk pengangkutan sampah medis dari setiap ruangan.

Proses pembuangan sampah medis untuk semua Puskesmas di Kabupaten Banyumas di bagi 5 titik TPS antaranya Rumah Sakit TB Paru, Puskesmas I Cilongok, Puskesmas I Sumpiuh, Puskesmas Jatilawang, dan Puskesmas I Sokaraja. Dimana setiap puskesmas harus mengirimkan ke TPS oleh Petugas Sanitarian Puskesmas masing-masing yang sebelumnya sampah di timbang terlebih dahulu. Setiap TPS sampah medis akan di angkut oleh PT. Jasa Medivest setiap 1 bulan sekali. Proses pengolahan sampah medis padat di puskemsas seluruh Kabupatan Banyumas bekerja sama dengan PT. Jasa Medivest dimana sudah ada surat perjanjian kerjasama.

Pendanaan setiap puskesmas berbeda-beda karena sampahnya pun jumlahnya berbeda dari setiap puskesmas akan tetapi petugas Cleaning service tidak tau masalah berapa anggaran yang di sediakan puskesmas untuk pengolahan limbah medis.

Penggunaan alat pelindung diri sangatlah penting dalam pengolahan limbah padat dimana kendalanya adalah tertusuk jarum suntik dan bau yang menyengat .dari 4 puskesmas semua petugas cleaning service pernah megalami tertusuk jarum suntik. Dan paling yang rawan adalah puskesmas di mana yang terdapat unit TPS karna bukan hanya 1 sumber saja limbah tetapi dari puskesmas yang lain juga akan di tampung di TPS.

Hasil Checklist Pengolahan Sampah Medis Padat setiap Puskesmas memenuhi syarat semua sesuai dengan Kepmenkes No.1428 / Menkes / SK/ XII / 2006.

Proses pengolahan sampah yang di lakukan setiap puskesmas yang di teliti sama yaitu dari mulai penimbulan, Pewadahan, pengumpulan, pengangkutan pengolahan dan pembuangan akhir sudah sama semua diamana sudah ada tempat sampah yang terpisah antar sampah medis dan non medis dan tempat sampahnya pun sudah tertutup dan kedap air dan di lapisi dengan plastik bewarna kuning dan hitam. Untuk pengangkutan sampah medis padat sendiri sudah di lakukan setiap hari oleh petugas cleaning servise yang ada di setiap puskesmas. Tetapi khusus untuk safety box di angkut menuggu penuh.

Kendala dari ke empat puskesmas yang di teliti hampir semuanya sama di mana masih kurangnya ruanagn tempat penampungsn untuk sampah medis padat yang disediakan. Terutama pada Puskesmas 
yang di tunjuk sebagai TPS atau pengepul seharusnya lebih baik lagi dalam penampungan sampah medisnya. Dan kurangnya alat pelindung diri yang di sediakan oleh pihak puskesmas maupun pihak ketiga.

\section{Pembahasan}

Analisis Pengolahan Limbah Medis di Setiap Puskesmas.Tingkat Pengetahuan Petugas PuskesmasBerdasarkan hasil penelitian yang dilakukan terkait sejauh mana pengetahuan petugas medis dan petugas non medis tentang limbah medis padat, para informan dari Puskesmas I Sokaraja, Puskesmas I Cilongok, Puskesmas II Cilongok, dan Puskesmas II Kembaran memberikan pendapat yang relatif sama bahwa limbah medis adalah limbah sisa hasil pelayanan medis yang sudah tidak terpakai, seperti spet, jarum sunti, verban, botol infus, kain kasa, kapas, botol suntik dan lain-lain.

Menurut KepMenkesRI

No. 1428/Menkes/SK/XII/2006, yang dimaksud dengan limbah medis puskesmas adalah semua limbah yang dihasilkan dari kegiatan puskesmas dalam bentuk padat dan cair. Berdasarkan hasil observasi di ke empat puskesmas terhadap para petugas medis dan non medis didapatkan hasil yang hampir sama, bahwa ke empat Puskesmas I Sokaraja, Puskesmas I Cilongok, Puskesmas II Cilongok dan Puskesmas II Kembaran mempunyai pengetahuan cukup memadai tentang limbah medis padat dan jenisnya. Kebanyakan mereka mengetahui bahwa yang dimaksud dengan limbah medis padat adalah limbah sisa hasil pelayanan medis yang sudah tidak terpakai, seperti spet, jarum sunti, verban, botol infus, kain kasa, kapas, botol suntik dan lain-lain.

Proses Timbulnya Limbah Medis Padat Pada Setiap Puskesmas.Puskesmas I Sokaraja dan Puskesmas I Cilongok

Penimbulan sampah medis di Puskesmas I Sokaraja dan Puskesmas I Cilongok berasal dari setiap ruangan menghasilkan limbah medis padat, sedangkan paling banyak yang menghasilkan IGD, dan rawat inap hampir semua ruangan yang melayani tindakan medis menimbulkan limbah medis padat di antaranya KIA, Laboratorium, Poli Gigi dll.Limbah medis di timbulkan setiap harinya berbeda-beda jumlahnya tergantung dari banyaknya pasien yang di tangani.Berdasar observasi pada saat wawancara berlangsung para petugas mengaku banyak timbulnya limbah medis terdapat pada Ruang IGD karena di mana untuk puskesmas yang terdapat rawat inapnya untuk pemeriksaan umum di tangani oleh IGD.

Puskesmas II Cilongok dan Puskesmas II Kembaran.Penimbulan sampah medis di Puskesmas II Cilongok dan Puskesmas II Kembaran berasal dari setiap ruangan menghasilkan limbah medis padat, sedangkan paling banyak yang menghasilkan sampah medis padat pada ruangan Pemeriksaan Umum, hampir semua ruangan yang melayani tindakan medis menimbulkan limbah medis padat di antaranya KIA, Laboratorium, Poli Gigi dll.
Limbah medis di timbulkan setiap harinya berbeda-beda jumlahnya tergantung dari banyaknya pasien yang di tangani.Berdasar observasi pada saat wawancara berlangsung para petugas mengaku banyak timbulnya limbah medis terdapat pada Ruang Pemeriksaan Umum.Penimbulan yaitu dimana setiap ruangan menghasilkan limbah medis padat, sedangkan paling banyak rawat inap, KIA, unit emergency dan bedah termasuk ruang perawatan, unit laboratorium, ruang mayat, phatology dan autopsy, unit perawatan dan unit isolasi.Tahap penimbulan meliputi : minimalisi, pemanfaatan kembali dan daur ulang sampah medis, pemilahan sampah medis. (A. Pruss, dkk, 2005, h. 64).

Tahap penimbulan dari semua puskesmas hampir semuanya sama yaitu dari unit yng terdapat tindakan medis akan tetapi untuk Puskesmas I Sokaraja dan I Cilongok timbulnya sampah medis padat terbanyak pada ruangan Instalasi Gawat Darurat (IGD). Dimana untuk pelayanan tidakan medis di balai pemeriksaan umum akan di tangani oleh IGD sehingga perlu adanya tempat sampah yang memenuhi dan terawat dengan baik.

Jenis pemilahan limbah telah dilakukan oleh ke empat puskesmas tersebut dengan teknik yang berbeda, di mana Puskesmas I Sokaraja memilahkan tempat limbah medis dan non medis dengan pelabelan, pembedaan kantong plastik warna tempat sampah, sehingga langsung oleh petugas cleaning service. di Puskesmas I Cilongok memilahkan tempat limbah medis dan non medis dengan pelabelan, perbedaan warna kantong plastik sampah, sementara di Puskesmas II Cilongok sudah ada pelabelan tempat limbah akan tetapi pembedaan warna kantong plastik belum dimana masih menggunakan kantong plastik bewarna hitam. Sedangkan untuk Puskesmas II Kembaran belum ada pelabelan di setiap tempat sampah dan belum juga ada pembedaan kantong plastik sehingga masih menggunakan kantong plastik bewarna hitam.

Pemisahan limbah belum sepenuhnya memenuhi standar, karena belum menggunakan kantung plastik dengan warna-warna yang berbeda, yang menunjukkan ke mana plastik harus diangkut untuk insinerasi atau dibuang (Pruss, 2005).Benda tajam dan jarum yang menurut Kepmenkes RI No. 1428/MENKES/SK/XII/2006 harus dimasukkan kedalam wadah khusus seperti botol atau safety box, namun diantara ke empat Puskesmas di Kabupaten Banyumas, sudah melakukan hal tersebut.

Sebenarnya penempatan limbah medis menggunakan kantong plastik belum memenuhi standar kesehatan, wadah limbah medis harus terbuat dari bahan yang kuat, ringan, tahan karat, kedap air, dan permukaan dalamnya halus. Di samping itu, limbah medis yang telah kantong plastik masih memungkinkan adanya kebocoran dan akan memperbesar risiko kontaminasi (Aris, 2008).Dalam pewadahan dari ke-empat puskesmas mempunya wadah sampah yang sama dan memenuhi syarat yaitu 
kuat, ringan, tahan karat, anti bocor, anti tusuk dan kedap air, tempat sampah mudah dibersihkan dan dikosongkan, tempat sampah tertutup dan berfungsi dengan baik, dan dilapisi kantong plastik sesuai standar kuning untuk sampah medis, dan hitam untuk sampah non medis. Akan tetapi untuk Puskesmas II Cilongok dan II Kembaran dalam pewadahan masih menggunakan kantong plasti bewarna hitam untuk sampah medis yang seharusnya bewarna kuning.

Sampah medis dari setiap ruangan tentunya sudah di pilah oleh petugas medis.Karena sudah di sediakannya tempat sampah 3 jenis.Tempat sampah medis dengan kantong plastik bewarna kuning, tempat sampah non medis dan safety box untuk benda tajam.

Akan tetapi dari ke empat Puskesmas tersebut masih adanya tercampurnya sampah medis dan non medis. Hal ini di sebabkan akan adanya kekeliruan petugas medis yang membuang sampah pada tempatnya. Sehingga petugas cleaning service harus memilahnya lagi dan rawan akan kecelakaan kerja karena belum adanya pengguanaan alat pelindung diri.

Pengumpulan Limbah Medis Padat Pada Setiap Puskesmas. Puskesma I Sokaraja dan Puskesmas I CIlongok.Sampah medis yang dihasilkan dari setiap kegiatan puskesmas disetiap ruangan dikumpulkan ke tempat penampungan sampah medis sementara yang sudah dilapisi kantong plastik kuning, untuk sampah medis infeksius dan safety box untuk sampah medis benda tajam, yang sebelumnya telah di timbang terlebih dahulu. Untuk pengankutan sendiri dilakukan setiap hari sekali pada waktu sore hari oleh petugas cleaning service.Akan tetapi hanya untuk sampah dengan kantong plastik kuning saja, untuk safety box di angkut menunggu penuh. Untuk penampungan sementara sampah medis Puskesmas I Sokaraja adalah salah satu dari pengepul puskesmas lainya di antaranya: Puskesmas I Sokaraja, Puskesmas II Sokaraja, Puskesmas I Kembaran, Puskesmas II Kembaran, Puskesmas I Sumbang, Puskesmas II Sumbang, Puskesmas Somagede, dan Puskesmas Banyumas. Untuk penampungan sementara sampah medis Puskesmas I Cilongok adalah salah satu dari pengepul puskesmas lainya di antaranya: Puskesmas Karanglewas, Puskesmas I Cilongok, Puskesmas II Cilongok, Puskesmas I Ajibarang, dan Puskesmas II Ajibarang.

Puskesmas II Cilongok dan Puskesmas II Kembaran.Sampah medis yang dihasilkan dari setiap kegiatan puskesmas disetiap ruangan dikumpulkan ke tempat penampungan sampah medis sementara yang sudah dilapisi kantong plastik, untuk sampah medis infeksius, dan safety box untuk sampah medis benda tajam. untuk pengankutan sendiri dilakukan setiap hari sekali pada waktu sore hari oleh petugas cleaning service. Akan tetapi untuk sampah dengan kantong plastik saja, untuk safety box di kumpulkan menunggu penuh. Sedangkan untuk penampungan masih belum ada ruangan khusus untuk penampungan sampah sehingga masih tercampur dengan barang-barang yang lain. Setelah sampah sudah banyak maka petugas Sanitarian harus mengantarkan ke pengepul sampah medis yang telah di tentukan yang sebelumnya telah di timbang terlebih dahulu.Dimana tempat pengepulnya adalah Puskesmas I Cilongok untuk puskesmas II Cilongok.Dan tempat pengepul untuk Puskesmas II Kembaran adalah Puskesmas I Sokaraja.

Untuk ke empat Puskesma Sudah mengumpulkan sampah medis setiap sehari sekali pada sore hari untuk sampah medis yang pada kantong plastik kuning, sedangkan sampah medis benda tajam yang berada padaa safety box di kumpulkan menunggu penuh.

Pengangkutan Limbah Medis Padat Pada setiap Puskesmas.Puskesmas I Sokaraja dan Puskesmas I Cilongok.Untuk Puskesma I Sokaraja sendiri dimana pengangkutan dilakukan dengan menggunakan grobak khususu yang disediakan oleh pihak ketiga (PT. Jasa Medivest) dimana Puskesmas sebagai Pengepul Sampah medis dari puskesmas lain di fasilitasi grobak pengangkut dan alat pelindung diri untuk petugas. Akan tetapi dalam penangananya masih belum adanya alat pelindung diri yang di sediakan, dan tempat penampungan masih dalam kondisi tidak terawat, diding masih menggunakan triplek kayu dan banyaknya sampah yang berceceran di TPS yang seharusnya berada dalam kantong plastik dan safety box.

Puskesmas I Cilongok dimana pengangkutan dilakukan dengan menggunakan grobak khususu yang disediakan oleh pihak ketiga (PT. Jasa Medivest) Puskesmas sebagai pengepul sampah medis dari Puskesmas lain di fasilitasi grobak pengangkut dan alat pelindung diri untuk petugas. Akan tetapi dalam penangananya masih belum adanya alat pelindung diri yang di sediakan oleh pihak ke tiga akan tetapi penyediaan alat pelindung diri sudah di sediakan oleh pihak Puskesmas untuk tempat penampungan masih dalam kondisi tercampur dengan barang-barang lain dan letaknya berada pada di dalam puskesmas dan dekat dengan ruang perawatan pasien. Yang seharusnya tempat penampungan sampah medis harus mudah di jangkau oleh kendaran, dan jauh dari ruang perawatan.

Sedangkan pengangkutan menggunakan kereta dorong, dan dibersihkan secara berkala serta petugas pelaksana dilengkapi dengan alat proteksi dan pakaian kerja khusus, pengangkutan sampah medis ke tempat pembuangan di luar (off-site) memerlukan prosedur pelaksanaan yang tepat dan harus dipatuhi petugas yang terlibat. Prosedur tersebut termasuk memenuhi peraturan angkutan lokal yaitu diangkut dalam kontainer khusus, harus kuat dan tidak bocor (Hapsari, 2010).

Pengangkutan menuju tempat pengepul yang belum dilakukan secara terjadwal untuk Puskesmas II Cilongok dan II Kembaran.Sehingga tempat sampah yang di hasilkan dalam keadaan rusak karena 
lamanya penyimpanan dan tidak di angkut untuk diserahkan kepada pengepul.Dimana pengepul untuk Puskesmas II Cilongok adalah Puskesmas I Cilongok dan Puskesmas II Kembaran adalah Puskesmas I Sokaraja.

Pembuangan Akhir Limbah Medis Padat Pada Setiap Puskesmas. Puskesmas I SokarajaPembuangan akhir di lakukan oleh pihak ketiga (PT. Jasa Medivest) yang akan di angkut setiap sebulan sekali menggunakan truk khusus. Dimana TPS setiap bulanya mengalami jumlah kenaikan sampah yang tidak relatif, paling banyak 250 kg/bulan untuk Puskesmas I Sokaraja.Sampah medis langsung diangkut semua ke dalam truk khusus untuk di musnakan oleh PT. Jasa Medivest.

Puskesmas I Cilongok.Pembuangan akhir di lakukan oleh pihak ketiga (PT. Jasa Medivest) yang akan di angkut setiap sebulan sekali menggunakan truk khusus. Dimana TPS setiap bulanya mengalami jumlah sampah yang tidak relatif, paling banyak 350 $\mathrm{kg} / \mathrm{bulan}$.Sampah medis langsung diangkut semua ke dalam truk khususu untuk di musnakan oleh PT. Jasa Medivest.Akan tetapi terkadang juga sampah yang berapa di TPS tidak terangkut semua karena kondisi yang sudah penuh pada truk angkut.Sehingga terdapat penumpukan sampah medis yang banyak pada TPS.

Puskesmas II Cilongok. Pembuangan akhir di lakukan oleh pihak ketiga (PT. Jasa Medivest) yang akan di angkut setiap sebulan sekali menggunakan truk khusus. Dimana petugas sanitarian harus mengantarkan ke Puskesmas I Cilongok untuk di tampung sebelum pihak ketiga mengambilnya.

Puskesmas II Kembaran. Pembuangan akhir di lakukan oleh pihak ketiga (PT. Jasa Medivest) yang akan di angkut setiap sebulan sekali menggunakan truk khusus. Dimana petugas sanitarian harus mengantarkan ke Puskesmas I Sokaraja untuk di tampung sebelum pihak ketiga mengambilnya.

Persyaratan pembuangan akhir sampah medis sesuai peraturan yang telah ditetapkan oleh Kepmenkes RI No 1204/Menkes/SK/X/2004 adalah :Sampah medis tidak diperbolehkan dibuang langsung ke tempat pembuangan akhir sampah domestik sebelum aman bagi kesehatan.Cara dan teknologi pengolahan atau pemusnahan sampah medis disesuaikan dengan kemampuan rumah sakit dan jenis sampah medis yang ada.Dengan pemanasan menggunakan otoklaf atau dengan pembakaran menggunakan incenerator.

Dimana sekarang untuk pemusnahan limbah medis padat harus benar-benar harus tidak mencemari lingkungan. Sehingga puskesmas harus bekerja sama dengan pihak ketiga yang terdapat sarana untuk pemusnahan limbah medis padat.

Untuk seluruh puskesmas di kabupaten banyumas sudah ada perjajian jasa pembuangan dan pemusnahan sampah medis oleh PT. Jasa Medivest. Sehingga puskesmas hanya membayar kepada pihak Medivest saja dengan harga sampah medis padat Rp.
12.000/Kg. Dimana PT. Jasa Medivest akan mengankut smapah-sampah dari Puskesmas pengepul pada tiyap satu bulan sekali. Namun ada kendala dalam pengagkutan yang di lakukan pada Puskesmas I Cilongok dimana tidak semua sampah medis padat yang berada di puskesmas terangkut semua.

Untuk Puskesmas II Cilongok dan II Kembaran dimana pengangkutan sampah medis padat kepada pengepul belum terjadwal.Dan kedaraan untuk mengangkutnya pun belum ada sehingga terpaksa menggunakan ambulan.

Pembiayaan Untuk Pengolahan Limbah Medis Padat Setiap Puskesmas. Puskesmas I Sokaraja.Pendanana untuk pengolahan sampah medis padat yang ada pada puskesmas sebesar Rp. 2.000.000 / tahun. Belum sama pendaan alat pelindung diri

Puskesmas I Cilongok.Pendanaan untuk pengolahan limbah medis padat di puskesmas per tahunya sebesar Rp 2.300.000. untuk sampah medis padat belum dengan alat pelindung dirinya

Puskesmas II Cilongok. Pendanaan untuk pengolahan limbah medis padat di puskesmas per tahunya sebesar Rp 2.500.000. untuk sampah medis padat belum dengan alat pelindung dirinya.

Puskesmas II Kembaran. Pendanaan untuk pengolahan limbah medis padat di puskesmas per tahunya sebesar Rp 1.500.000. untuk sampah medis padat belum dengan alat pelindung dirinya.

Pendanaan dapat berasal dari sektor swasta atau dari satu atau beberapa tingkat pemerintahan. Untuk instansi kesehatan milik pemerintah, pemerintah dapat menggunakan pendapatan milik negara untuk membiayai sistem pengelolaan sampah, sedangkan bagi instansi kesehatan swasta, pemerintah dapat langsung memberlakukan kebijakan langsung yang mewajibkan swasta untuk menerapkan sistem pengelolaan sampah medisnya sendiri.

Membuat prosedur akutansi untuk mendokumentasikan biaya yang dikeluarkan dalam pengelolaan sampah medis.Biaya untuk pengumpulan yang terpisah, pengemasan yang tepat dan penganganan di tempat merupakan biaya internal instansi dan dikeluarkan dalam bentuk gaji dan biaya persediaan.Biaya sampah medis harus dimasukkan dalam kolom yang berbeda, hal ini memungkinkan dilakukannya perbandingan biaya antar periode dan membantu mengurangi biaya pengolahan. (A. Pruss, dkk, 2005, h. 154-147).

Pendanan setiap puskesmas berbeda-beda karena sampahnya pun jumlahnya berbeda dari setiap puskesmas akan tetapi petugas Cleaning service tidak tau masalah berapa anggaran yang di sediakan puskesmas untuk pengolahan limbah medis.

Dimana setiap puskesmas sudah terakuntasi untuk pendaanaan pengolah limbah medis padat tiyap tahunya akan tetapi jumlah limbah medis tentunya akan di pengaruhi oleh jumlah pasien yang melakukan tidakan medis. Akan tetapi anggaran 
sudah di keluarkan untuk per tahunya oleh pihak puskesmas.

Penyediana Alat Pelindung Diri Untuk Petugas cleaning service.Alat pelindung diri yang disediaka setiap puskesmas mempunyai dampak penting untuk pekerja dimana kenyamana dan resiko akan kecelakaan kerja dapat di atasi dengan baik sehingga tidak ada kejelakanan yang di akibatkan oleh pekerjaan. Namun dimana 4 puskesmas yang di teliti masih ada juga yang belum menyediakan alat pelindung diri.Sementara Puskesmas I Sokaraja, Puskesmas II Cilongok, Puskesmas II Kembaran belum terdapat penyediaan alat pelindung diri untuk penanganan limbah medis padat.Hanya Puskesmas I Cilongok yang sudah ada penyediaan alat pelindung diri.Diama menurut Petugas P2PL alat pelindung diri sudah di sediakan oleh PT. Jasa Medivest untuk Puskesmas yang terdapat tempat pengepul limbah medis padat.

Menurut Peraturan Menteri Tenaga Kerja dan Transmigrasi RI No.8/MEN/VII/2010, alat pelindung diri (APD) atau personal protective equipment didefinisikan sebagai alat yang mempunyai kemampuan untuk melindungi seseorang yang fungsinya mengisolasi sebagian atau seluruh tubuh dari potensi bahaya di tempat kerja.Menurut permenaker no.8 tahun 2010 bahwa setiap pengusaha wajib menyediakan alat pelindung diri (APD) bagi pekerja/buruh di tempat kerja.

Penggunaan alat pelindung diri sangatlah penting dalam pengolahan limbah padat dimana kendalanya adalah tertusuk jarum suntik dan bau yang menyengat. Dari 4 Puskesmas semua petugas cleaning service pernah megalami tertusuk jarum suntik. Dan paling yang rawan adalah puskesmas di mana yang terdapat unit TPS karna bukan hanya 1 sumber saja limbah tetapi dari puskesmas yang lain juga akan di tampung di TPS. Dan penyedian alat pelindung diri pun masih belum memenuhi syarat dari ke empat puskesmas.Dan kurangnya komunikasi antar pihak P2PL.Dimana PT.Jasa Medivesrt sudah menyediakan alat pelindung diri untuk petugas puskesmas yang terdapat TPS.

Pemeliharaan dan kontrol terhadap alat pelindung diri penting karena alat pelindung diri sensitife terhadap perubahan tertentu, punya masa kerja tertentu dan APD dapat menularkan beberapa jenis penyakit jika secara bergantian.

Pada dasarnya proses pengelolaan limbah medis padat di Puskesmas I Sokaraja, Puskesmas I Cilongok, Puskesmas II Cilongok dan di Puskesmas II Kembaran berbeda,Puskesmas I Sokaraja, Puskesmas I Cilongok, Puskesmas II Cilongok dan Puskesmas II Kembaran di Kabupaten Banyumas. Limbah medis padat yang seharusnya dipisahkan antara limbah infeksius dan non infeksius, akan tetapi kadang di temukan sampah yang tercampur.

Pelabelan tempat sampah antara limbah medis dan non medis hanya dilakukan oleh Puskesmas I Sokaraja dan Puskesmas I Cilongok, sedang
Puskesmas II Cilongok dan Puskesmas II Kembaran tidak melakukan pelabelan. Pemisahan limbah medis dan non medis menurut ketentuan harus dipisahkan dengan menggunakan warna kantong plastik yang berbeda yaitu kantong plastik berwarna kuning untuk sampah infeksius dan kantong plastik berwarna hitam untuk sampah domestik (non medis) serta terpisah antara sampah basah dan kering, namun Puskesmas II Cilongok dan Puskesmas II Kembaran memisahkan sampah medis dengan kantong hitam dan sampah non medis dengan warna kantong hitam. Sama tidak ada perbedaan yang seharusnya ada perbedaan.

Pemisahan benda tajam dan jarum (dimasukan dalam botol atau safety box), sudah dilakukan oleh keempat puskesmas akan tetpi terkadang masih di temukan sampah medis benda tajam masuk kedalam sampah medis bukan masuk ke safety box. Pengumpulan limbah di tempat pengumpulan sementara dilakukan oleh Puskesmas I Sokaraja, Puskesmas I Cilongok pada TPS yang ada Puskesmas, untuk Puskesmas II Cilongok dan Puskesmas II Kembaran belum ada rruangan khususu penampungan sementara. Puskesmas II Cilongok dan Puskesmas II Kembaran mengirim limbah medis ke tempat pengepul yang telah di tentukan, untuk Puskesmas II Cilongok di kirim ke pengepul yang ada pada Puskesmas I Cilongok. Sedangkan untuk Puskesmas II kembaran di kirim kepada pengepul yang ada pada Puskesma I Sokaraja

Selanjutnya proses akhir pemusnahan limbah medis padat puskesmas menurut ketentuan harus menggunakan incenerator yang mempunyai kapasitas memusnahkan limbah infeksius yang memenuhi syarat, dimana puskesmas bekerja sama untuk pemusnahahn limbah medis padat dengan PT. Jasa Medivest. Dengan harga sampah medis padat Rp. $12.000 / \mathrm{Kg}$.

Dari uraian di atas nyatalah bahwa pengelolaan limbah medis baik Puskesmas I Sokaraja, Puskesmas I Cilongok, Puskesmas II Cilongok dan Puskesmas II Kembaran dapat dikatakan sudah sesuai dengan ketentuan yang berlaku yaitu ketentuan dalam pengelolaan limbah medis menurut Kepmenkes No 1428/MENKES/SK/XII/2006.

Masih banyak hal yang perlu diperbaiki dan mendapat perhatian dari pihak puskesmas agar tercipta lingkungan yang sehat baik dalam puskesmas itu sendiri maupun lingkungan sekitarnya yang menjadi tanggung jawab puskesmas.

Untuk ke empat Puskesmas mempunyai kendala yang relatif sama dimana belum adanya alat pelindung diri yang disediakan dan kuranya kesadaran bagi petugas medis yang mehasilkan sampah medsi dimana terkadang masih ada sampah yang tercampur. Sedangkan untuk Puskesmas II Cilongok dan II Kembaran belum adanya pelabelan dan kode warna plastik yang sesuai dengan aturan.

\section{IV.SIMPULAN DAN SARAN}




\section{Simpulan}

Berdasar hasil penelitian maka dapat ditarik beberapa kesimpulan sebagai berikut:

a. Proses pengolaan limbah medis di Puskesmas I Sokaraja, Puskesmas I Cilongok, Puskesmas II Cilongok dan di Puskesmas II Kembaran di Kabupaten Banyumas pada dasarnya memiliki proses yang sama yaitu dari Penimbulan, pemilahan limbah medis dan non medis, pengumpulan, pengangkutan limbah ke TPS, disimpan di TPS sampai penuh, kemudian dilakukan proses pembuangan akhir limbah medis padat yaitu melalui kerjasama dengan pihat ke tiga (PT. Jasa Medivest)

b. Secara keseluruhan proses pengelolaan limbah medis di Puskesmas I Sokaraja, Puskesmas I Cilongok, Puskesmas II Cilongok dan di Puskesmas II Kembaran di Kabupaten Banyumas sesuai dengan ketentuan yaitu Keputusan Menteri Kesehatan No.1428/Menkes/SK/XII/2006 tentang standar dan persyaratan kesehatan lingkungan puskesmas.

c. Kendala pada pengolahan limbah medis padat di Puskesmas I Sokaraja, Puskesmas I Cilongok, Puskesmas II Cilongok dan di Puskesmas II Kembaran di Kabupaten Banyumas adalah masih kurangnya kesadaran dari petugas medis yang menghasilkan sampah medis padat di mana masih sering di temukan sampah medis yang tercampur dengan sampah non medis. Penyedian alat pelindung diri (APD) yang kurang di sediakan oleh setiap Puskesmas sehingga petugas cleaning service rawan akan kecelakaan kerja saat bekerja. Untuk tempat penampungan sementara sampah medis setiap puskesmas belum memenuhi syarat di mana tempat penampungan smpah medis masih tercampur dengan barang lainya.

\section{Saran}

a. Bagi Tenaga Kerja Puskesmas di Kabupaten Banyumas

1. Untuk petugas medis diharapkan dapat membuang sampah medis yang dihasilkan dari kegiatan medis pada temopat yang sudah di sediakan sesuai dengan jenis sampah medis

2. Untuk petugas cleaning service selalu memeriksa atau memilah terlebih dahulu sebelum sampah diangkut ke tempat penampungan sementara, menata dengan baik limbah medis yang akan ditimbun, agar tidak berserakan dan membahayakan

3. Untuk petugas sanitarian puskesmas diharapkan selalu mengontrol dalam proses pengolahan sampah medis.

b. Bagi Puskesmas

1. Menyediakan dua jenis tempat sampah (limbah medis dan limbah non medis) di tiap unit pelayanan puskesmas, dan safety box untuk sampah medis tajam.
2. Melakukan pelabelan tempat sampah, yaitu label sampah medis dan sampah non medis.

3. Menyediakan kantong kresek berbeda warna untuk tempat sampah, misalnya warna kuning untuk sampah medis dan warna hitam untuk sampah non medis.

4. Menyediakan alat pelindung diri bagi cleaning service, yaitu masker pernafasan, sarung tangan bahan karet, clemek, dan sepatu boots.

c. Bagi Masyarakat

Diharapkan untuk semua pengunjung puskesmas supaya tidak membuang sampah sebarangan di lingkungan puskesmas dan membuang sampah sesuai dengan jenis sampah dengan tempat sampah yang telah di sediakan.

\section{DAFTARPUSTAKA}

Adisasmito, 2008, Audit Lingkungan Rumah Sakit, Jakarta : Rajawali Pers.

, 2009, Sistem Manajemen Lingkungan Rumah Sakit, Jakarta : Rajawali Pers.

Arifin M. 2009. Sanitasi lingkungan. http://inspeksisanitasi.blogspot.com/sanitasilingkungan.html. Diakses pada 8 Januari 2016 Pukul 09.25 WIB

Anies, 2006. Manajemen Berbasis Lingkungan Solusi mencegah dan Menanggulangi Penyakit Menular, Elex Media Komputendo, Jakarta

Djaja, 2006, Gambaran Pengolahan Limbah Cair di Rumah Sakit, Jakarta: Penerbit EGC.

Hapsari, 2010, Analisis Pengelolaan Sampah dengan Pendekatan Sistem di RSUD dr. Moewardi Surakarta. Tesis: Universitas Diponegoro Semarang

Kemenkes RI, 2015, Profil Kesehatan Indonesia tahun 2014, Jakarta : Kementerian Kesehatan RI.

Masri Singarimbun dan Sofian Effendi, 1997, Metode Penelitian Survai, Jakarta : LP3ES

Moleong, L.J. 2007, Metodologi Penelitian Kualitatif, Bandung : Remaja Rosdakarya.

Pruss.A, 2005, Pengelolaan Aman Limbah Layanan Kesehatan, Cetakan I, Jakarta: Penerbit EGC.

Sarwono.2006. Metode Penelitian Kuantitatif dan Kualitatif.Yogyakarta : Graha Ilmu.

Siswanto, A. 1991.Ergonomi.Balai Hiperkes dan Keselamatan Kerja. Surabaya: Jawa Timur 
Sugiyono, 2009. Metode Penelitian Kuantitatif, Kualitatif dan R\&D. Bandung: Alfabeta.

Sukantora, 2010, Pengolahan Limbah Klinis Tajam Puskesmas di Kota Yogyakarta tahun 2010, skripsi, Yogyakarta : Universitas Gajah Mada.

Sulastomo, 2000, Manajemen Kesehatan, Jakarta : PT. Gramedia Pustaka Utama.

Suparko, 2014, Studi Pengelolaan Sampah Medis Di Rumah Sakit Umum Daerah Prof. Dr. Margono Soekarjo Purwokerto. KTI: Poltekkes Semarang.

Suryati, dkk, 2009, Evaluasi Pengolahan Limbah Cair di RSU Cut Meutia Kota Lhokseumawe. Jurnal Kedokteran Nusantara, Volume 42, No. 1, Maret 2009, hlm. 41-47.

Trihono. (2005). ARRIMES: Manajemen Puskesmas Berbasis Paradigma Sehat. Jakarta : CV. Sagung Seto.

www.its.ac.id, 2011, Identifikasi Pola Penyebaran Limbah Padat B3 Dari Fasilitas Kesehatan Di Surabaya Timur. Institut Teknologi Surabaya.Diakses pada tanggal 8 januari 2016. 